\title{
Liver Regeneration in Surgical Animal Models - A Historical Perspective and Clinical Implications
}

\author{
K.E. Mortensen ${ }^{a} \quad$ A. Revhaug ${ }^{b}$ \\ a Surgical Research Laboratory, Institute of Clinical Medicine, University of Tromsoe, and bepartment of \\ Gastrointestinal Surgery, University Hospital of North Norway, Tromsoe, Norway
}

\section{Key Words}

Animal models $\cdot$ Experimental research $\cdot$ Liver regeneration $\cdot$ Partial hepatectomy $\cdot$ Split liver

\begin{abstract}
Methods/Aims: Despite improved preoperative evaluation, surgical techniques and perioperative intensive care, some patients still experience postoperative liver failure in part due to insufficient regeneration. The aim of this review is to give the reader a historical synopsis of the major trends in animal research on liver regeneration from the early experiments in 1877 up to modern investigation. A major focus is placed on the translational value of experimental surgery. Methods: A systematic review of the English literature published in Medline was undertaken with the search words 'pig, porcine, dog, canine, liver regeneration, experimental'. $\boldsymbol{R e}$ sults: The evolution of the various models tentatively explaining the process of liver regeneration is described. Conclusions: We conclude by emphasizing the importance of large-animal surgical research on liver regeneration as it offers a more integrated, systemic biological understanding of this complex process. Furthermore, in our opinion, a closer collaboration between the hepatologist, liver surgeon/ transplant surgeon and the laboratory scientist may advance clinically relevant research in liver regeneration.
\end{abstract}

Copyright ๑ 2010 S. Karger AG, Basel

\section{Introduction}

Modern liver surgery has seen the development of split-liver grafting [1] and more aggressive, multimodal treatment of primary and secondary liver malignancies, increasing the possibilities for resection [2]. Despite continuous improvement in the surgical technique and perioperative intensive care, some patients still experience deficient regeneration and functional failure in the socalled SFSS occurring after liver transplantation if the graft is of marginal size (graft weight/body weight ratio $<0.8 \%$ ) [3], or if the liver remnant is too small after extend-

Abbreviations: $A R=$ Amphiregulin; $C / E B P-\beta=$ CCAAT enhancerbinding protein- $\beta ; \mathrm{C} 3 \mathrm{a}=$ complement factor $3 \mathrm{a} ; \mathrm{C} 5 \mathrm{a}=$ complement factor $5 \mathrm{a}$; $E G F=$ epidermal growth factor; $F G F=$ fibroblast growth factor; HB-EGF = heparin-binding epidermal growth factor; $\mathrm{HGF}=$ hepatocyte growth factor; HSS = hepatic stimulatory substance; IGFBP-1 = insulin-like growth factor binding protein-1; IGF = insulin-like growth factor; IL = interleukin; iNOS = inducible nitric oxide synthase; Met = hepatocyte growth factor receptor; $M M P 9=$ matrix metalloproteinase 9; MT = metallothionein; MyD88 = myeloid differentiation factor 88; OSM = oncostatin M; PCS = portocaval shunt; $\mathrm{PHx}=$ partial hepatectomy; PPAR- $\alpha=$ proliferator-activated receptor- $\alpha$; PVA = portal vein arterialization; SCF = stem cell factor; SFSS = small-for-size syndrome; $T_{3}=$ triiodothyronine; $T G F=$ transforming growth factor; TIMP3 = tissue inhibitor of metalloproteinase 3; TNF = tumor necrosis factor; UPA = uroplasminogen activator; VEGF $=$ vascular endothelial growth factor.

\section{KARGER}

Fax +4161306 1234 E-Mail karger@karger.ch www.karger.com
Kim Erlend Mortensen

Surgical Research Laboratory

Institute of Clinical Medicine, University of Tromsoe

NO-9038 Tromsoe (Norway)

Tel. +47 9151 5756, Fax +47 7762 6605, E-Mail kimem@fagmed.uit.no 
ed hepatectomy ( $<25 \%$ functionally normal liver remaining) [2]. Postresectional liver dysfunction is also a problem with the increasing use of neoadjuvant chemotherapy for colorectal metastasis [4]. The vast amount of research performed on liver regeneration to date has had relatively little practical consequences for the patient with a failing liver except for the development of liver support systems such as the molecular adsorbent recirculating system, bridging the time to transplantation, re-transplantation or as a support during recuperation of the native liver [5]. Contemporary liver surgery is therefore in need of a better understanding of the mechanisms controlling liver regeneration in order to design new treatment strategies to support the functionally deficient and failing organ. At the same time, strategies are needed to enhance its regenerative capacity be it a small-for-size graft or a failing remnant after hepatectomy with or without neoadjuvant chemotherapy. The purpose of this literature review is therefore to summarize previous experimental in vivo research on liver regeneration in animals, beginning with the Eck fistula model in 1877 up to present-day investigations, focusing on how this field has developed as a result of the interplay between clinical challenges and preclinical surgical research (see table 1 for a chronological overview of the studies discussed below). The review is organized according to past and present general themes on liver regeneration and their development over time. For each theme, we aim to highlight residual controversies, formulate new hypotheses and suggest novel experimental models in which they could be tested.

By writing this review we aim to give the reader a historical overview of the major trends in animal research on liver regeneration with emphasis on the importance of in vivo models, the value of translational research, and the necessity of increased collaboration between the basic laboratory scientist and the clinician. In our opinion, these measures are necessary if we are to make any further progress in aiding the patient with a failing liver due to insufficient regeneration.

\section{Sinusoidal Hemodynamics and the Flow Theory}

The study of liver regeneration was largely triggered by Eck's seminal paper on complete PCS (Eck fistula) in dogs in 1877 [6] which led to the belief that the liver's homeostasis was not dependent upon portal blood perfusion. However, in 1893 this was contested by Hahn et al. [7] whose dogs did poorly with the Eck fistula, showing signs of liver atrophy, weight loss and encephalopathy. The changes incurred by PCS were for many ensuing years thought to be the result of a lack of sinusoidal distension and/or lack of portal flow through the liver (as opposed to a lack of the substances transported to the liver in the portal blood). The theory of sinusoidal distension was corroborated by Grindlay and Bollman [8] who in 1952 observed that the liver regenerated after a $70 \% \mathrm{PHx}$ in dogs when constricting the vena cava above the liver, and hence increasing the hepatic venous pressure (in a Budd-Chiari-like manner). The theory of liver volume and functional maintenance by sinusoidal flow per se received much support due to Child's model of portocaval transposition in 1953, where, after a $70 \% \mathrm{PHx}$ in dogs, the portal vein and vena cava inferior were switched surgically, resulting in the liver remnant receiving only systemic blood from the caudal stump of the vena cava inferior, and all portal blood being diverted to the cranial stump of the vena cava inferior [9]. The observation that the remnant liver (in the portocaval transposition group) regenerated by $50 \%$ seemed to support the theory that sinusoidal flow in itself was adequate to initiate and support liver regeneration, irrespective of the quality of the perfusate. Conceptually, the observations in both studies could have been the result of a systemic overflow of growth-stimulating factors from the upper gastrointestinal tract away from the portal circulation and back to the liver via the hepatic artery in Grindlay's experiments, and via the vena cava inferior in Child's experiments, but this possibility is not discussed in either article. Further solid support to the 'flow theory' came from several canine experiments conducted in the 1950s and early 1960s with PVA (after PCS) showing that this maneuver would not only arrest the changes incurred by the Eck fistula, such as 'meat intoxication', weight loss of the animals and liver atrophy [10-12], but also allow liver regeneration to occur after a $42 \%$ PHx [13]. However, several of these [11, 12] and other studies [14-16] also reported the development of vasculitis, periportal fibrosis, intima proliferation, lipid infiltration and the development of cirrhosis in long-term (5-year)-arterialized livers [12]. This would indicate the unphysiological nature of PVA. A note of interest at this point is the preceding work of Rous and Larimore [17] in 1920 which illustrated what they coined the phenomenon of 'parenchymal shift'. Upon ligating one of the portal vein branches in the rabbit, they observed ipsilateral atrophy and contralateral hypertrophy of the liver, postulating 'the liver is wholly a portal organ, finding its reason for being in the substances carried to it in the portal blood'. This study had clearly implicated the importance of the humoral effect of splanchnic inflow on liver homeostasis; however, the flow theory prevailed unchallenged until the mid 1960 s. 


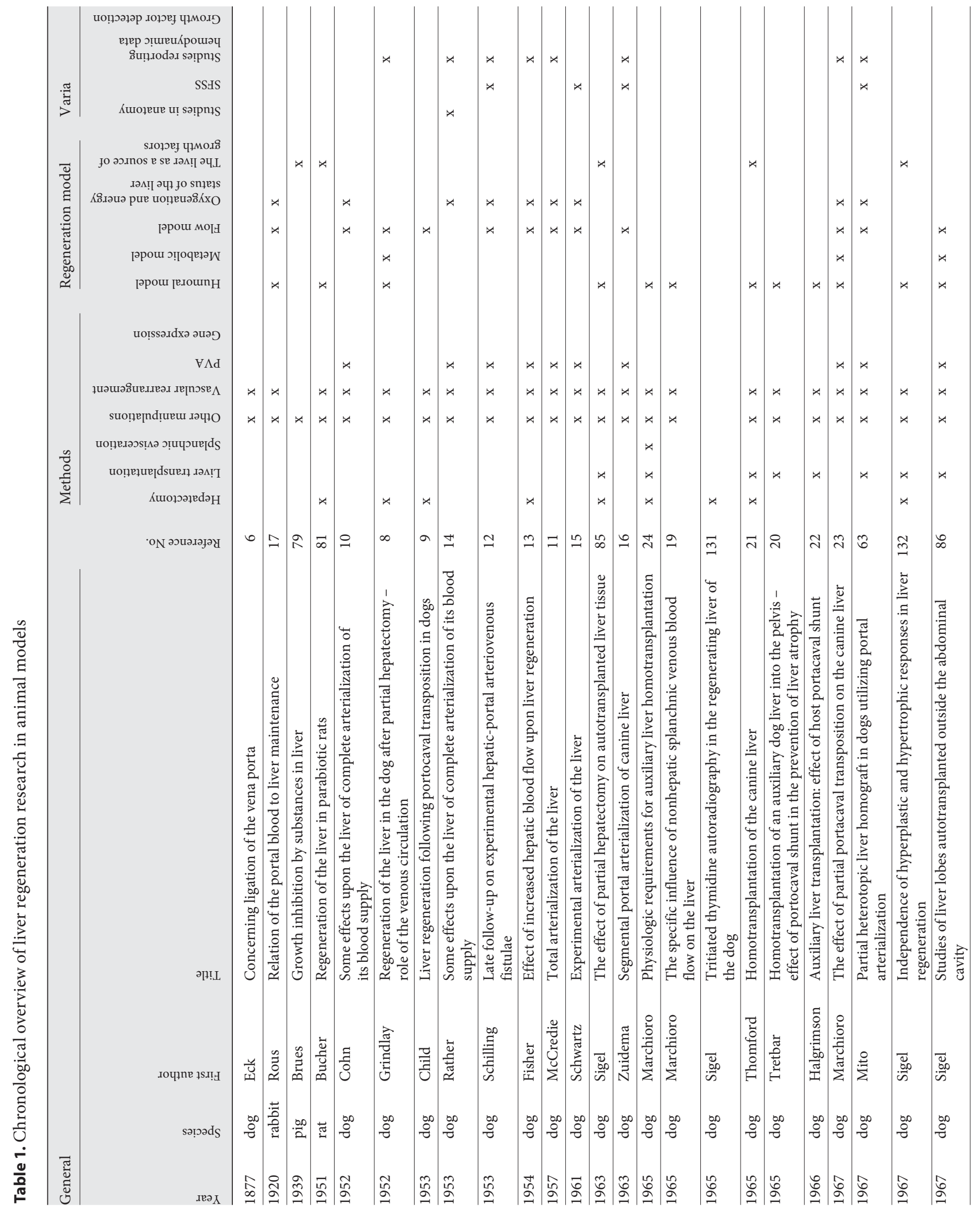




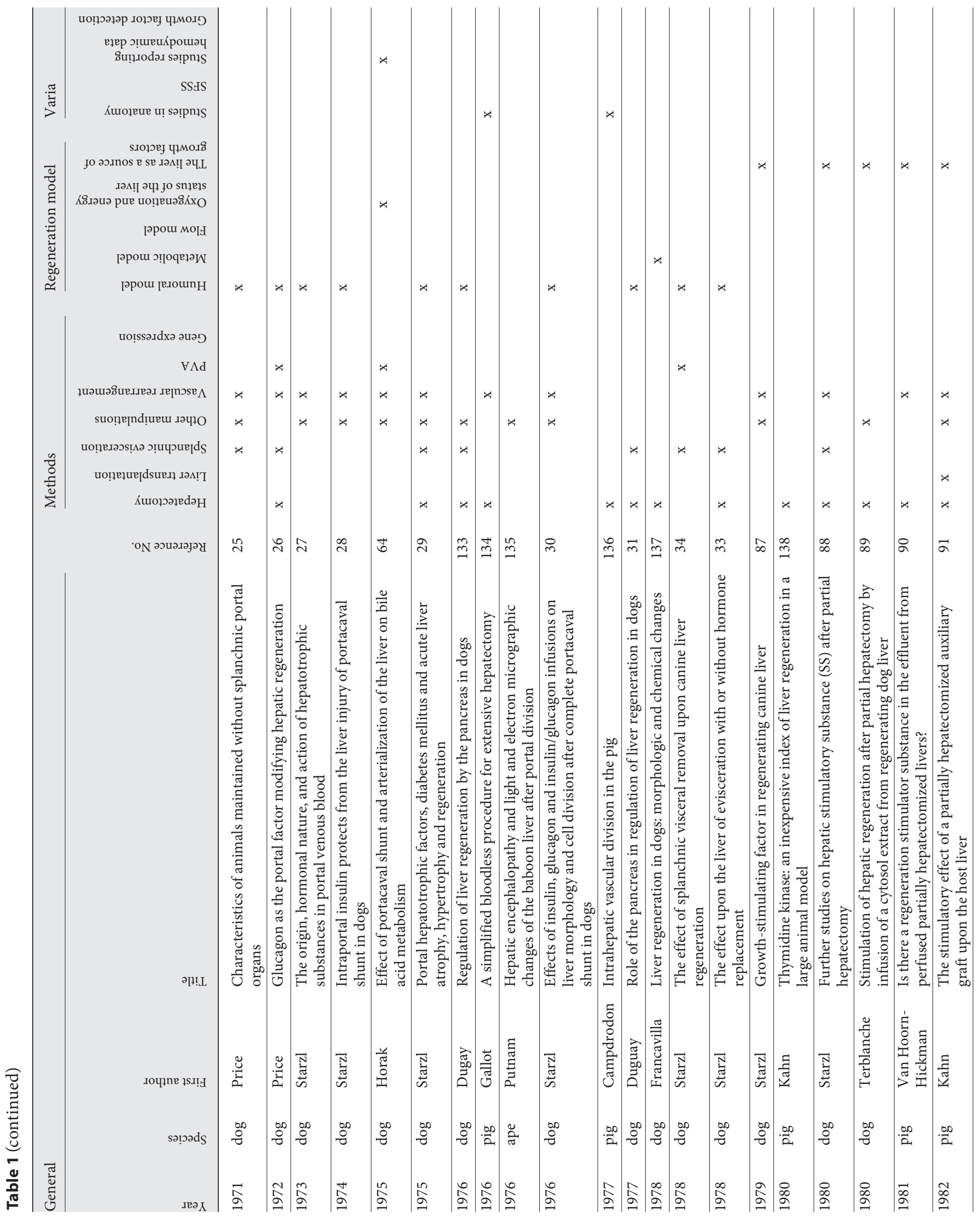




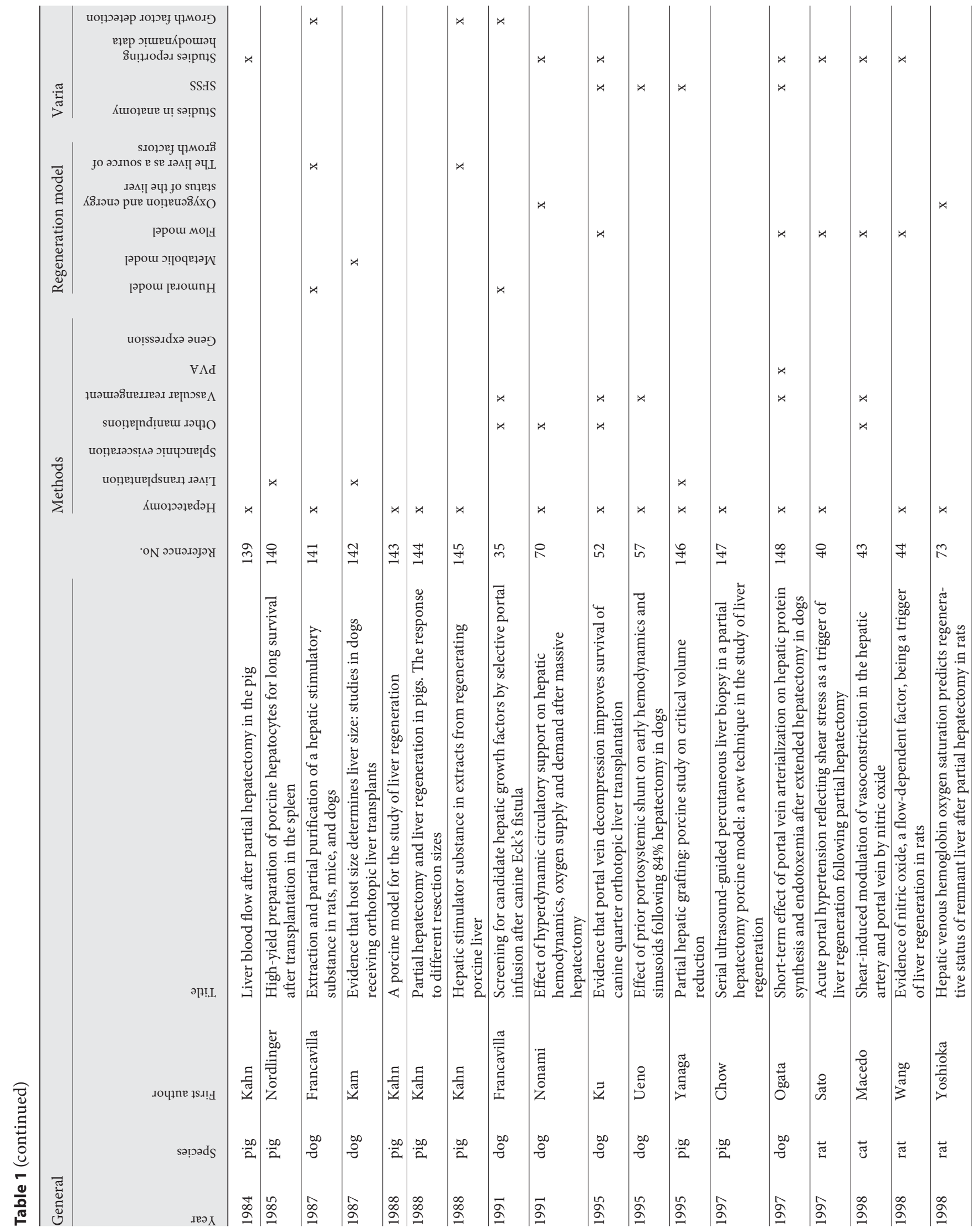




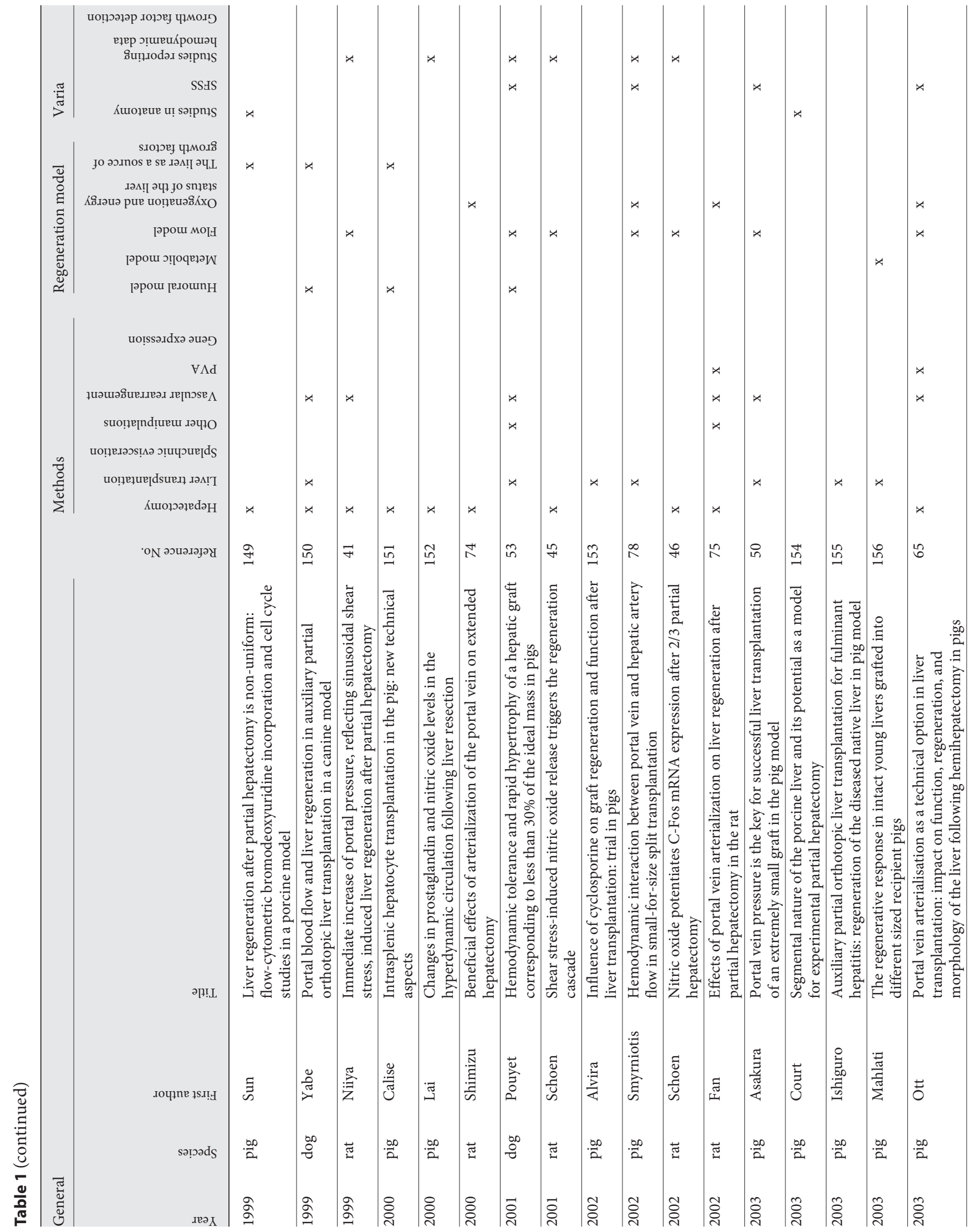




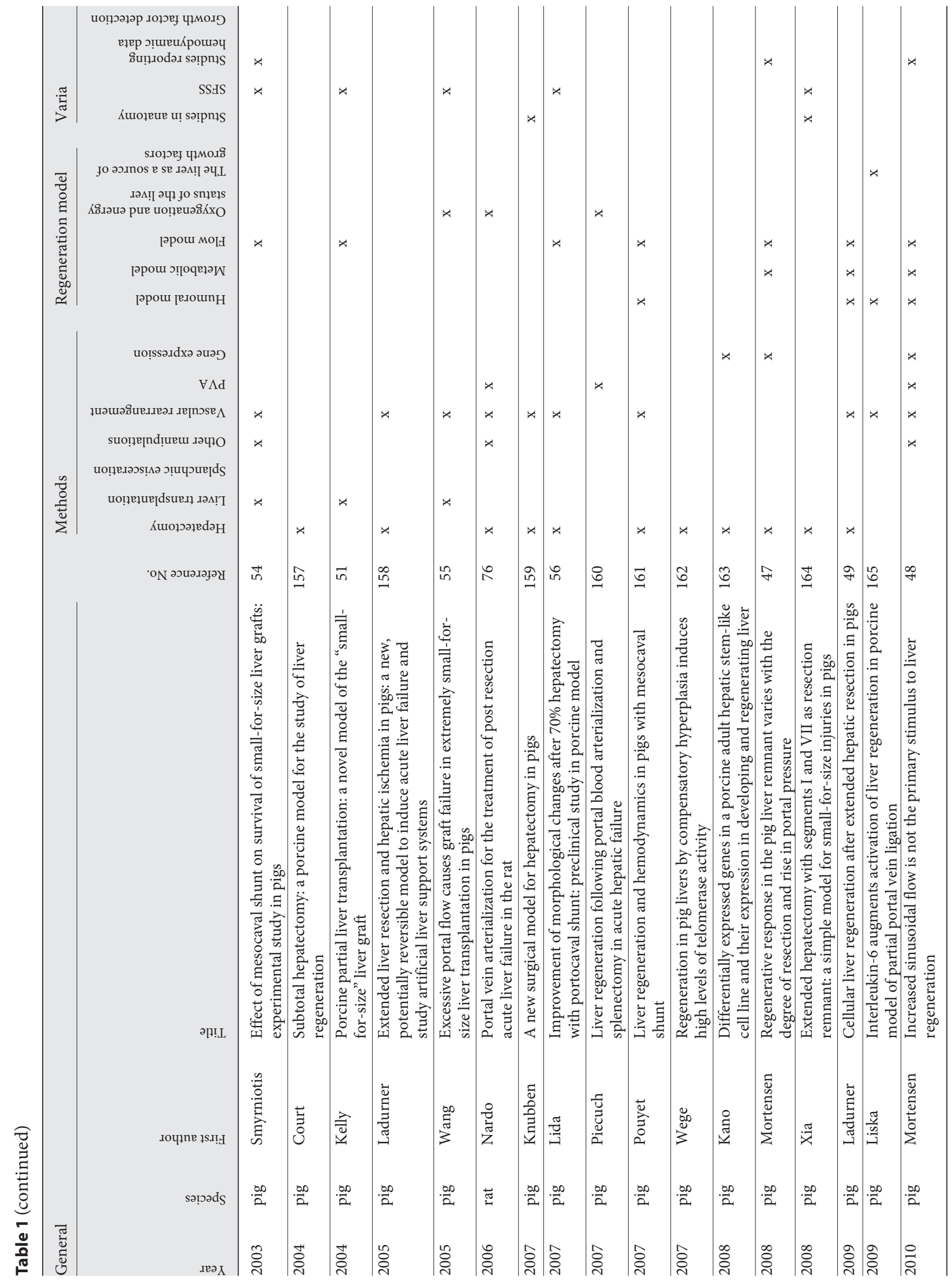


Table 2. Tabular overview of known priming factors, genuinely hepatotrophic factors, implicated hepatotrophic factors and inhibitory factors

\begin{tabular}{|c|c|c|c|c|c|}
\hline Factor & Priming & $\begin{array}{l}\text { Genuinely } \\
\text { trophic }\end{array}$ & $\begin{array}{l}\text { Impli- } \\
\text { cated }\end{array}$ & $\begin{array}{l}\text { Inhibi- } \\
\text { tory }\end{array}$ & $\begin{array}{l}\text { Refer- } \\
\text { ence }\end{array}$ \\
\hline TNF & $\mathrm{x}$ & & & & 98 \\
\hline IL-6 & $\mathrm{x}$ & & & & 99 \\
\hline HGF & & $\mathrm{x}$ & & & 100 \\
\hline TGF- $\alpha$ & & $\mathrm{x}$ & & & 101 \\
\hline EGF & & $\mathrm{x}$ & & & 102 \\
\hline $\mathrm{AR}$ & & $\mathrm{x}$ & & & 103 \\
\hline HB-EGF & & $\mathrm{x}$ & & & 104 \\
\hline SCF & & $\mathrm{x}$ & & & 105 \\
\hline OSM & & $\mathrm{x}$ & & & 106 \\
\hline Insulin & & $\mathrm{x}$ & & & 29 \\
\hline Bile acids & & & $\mathrm{x}$ & & 107 \\
\hline Serotonin & & & $\mathrm{x}$ & & 108 \\
\hline VEGF & & & $\mathrm{x}$ & & 109 \\
\hline IGF-II & & & $\mathrm{x}$ & & 35 \\
\hline $\mathrm{T}_{3}$ & & & $\mathrm{x}$ & & 35 \\
\hline Glucagon & & & $\mathrm{x}$ & & 26 \\
\hline Estrogens & & & $\mathrm{x}$ & & 110 \\
\hline Noradrenaline & & & $\mathrm{x}$ & & 38 \\
\hline Follistatin & & & $\mathrm{x}$ & & 111 \\
\hline TGF- $\beta$ & & & & $\mathrm{x}$ & 112 \\
\hline Activin & & & & $\mathrm{x}$ & 113 \\
\hline
\end{tabular}

\section{The Evolution of the 'Humoral Theory'}

With the advent of auxiliary liver grafting in the 1960s unveiling the phenomenon of graft atrophy due to the portal steal effect came the realization that there must be certain substances delivered to the liver in the portal blood only, upon which the organ is dependent to regenerate and/or maintain its volume and function [18]. One could no longer regard liver homeostasis as a result of mechanical portal flow stimuli (which was hypothesized by Rous and Larimore [17] 40 years earlier). A period of intense investigation followed from 1965 to 1978 with a large body of experiments revealing the importance of the hormonal and nutritional effect of portal blood on liver regeneration, in particular insulin (table 2). This period commenced with canine models of split portocaval transposition (one portal branch perfused with blood from the vena cava inferior and the other portal branch perfused with portal blood, with similar flow rates and oxygen tension). This eliminated the possible confounding effect that graft rejection could have had in causing graft atrophy in previous auxiliary transplantation ex- periments. After 3 months of split portocaval transposition in dogs, Marchioro et al. [19] observed hypertrophy with glycogen deposition, increased DNA synthesis and mitosis on the side receiving splanchnic blood and atrophy on the side receiving systemic blood. The importance of portal blood supply to the liver's homeostasis in auxiliary grafting was consequently corroborated the same year (1965) by Tretbar et al. [20], Thomford et al. [21] and Halgrimson et al. [22]. Marchioro et al. [23] also substituted the blood flow in one of the portal vein branches over 3 months, observing that increasing the flow and oxygen supply to one side of the liver could not compensate for the qualitative loss of the portal blood stimulus.

Given that the trophic substances seemed to be found in the portal blood, subsequent investigations were designed to disclose their origin. Separating the portal inflow coming from the upper gastrointestinal tract (distal stomach, duodenum, pancreas and spleen) from that originating from the small intestine (model of splanchnic flow division), Marchioro et al. [24] transplanted auxiliary liver grafts supplying them with portal blood from the small intestine only, while the native liver received pancreaticogastroduodenosplenic blood. This resulted in atrophy, centrilobular necrosis, cytoplasmic fat deposits in hepatocytes, hemosiderin deposits in Kupffer cells and collapse of the reticulin framework in the grafts [24]. Further research in the 1970s utilized various canine models of splanchnic evisceration: Price et al. [25, 26] eviscerated dogs, simultaneously performing portocaval transposition (maintaining liver perfusion with systemic blood), with or without glucagon infusion and suggested that glucagon was a main factor as it could reverse the many effects of portal blood deprivation. This was challenged by Starzl et al. [27] a year later in experiments of splanchnic flow division with diversion of the pancreaticogastroduodenosplenic venous blood to one half of the liver and blood from the small intestine to the other half resulting in atrophy of liver parenchyma not receiving pancreaticogastroduodenosplenic venous blood, postulating that the substance in question was insulin. This theory was later corroborated by the same investigator upon constructing an Eck fistula and infusing insulin into one of the portal vein branches, which limited the atrophy (on the side receiving insulin) caused by PCS [28] and further fortified by observing liver atrophy and lack of regeneration after PHx in alloxan-induced diabetes mellitus in dogs [29]. However, contrary to the findings of Starzl et al. [30], Duguay and Orloff [31] did find some additive effect of glucagon infusion in addition to insulin in 1976. 
At this stage, it became apparent that the liver regeneration observed in Child's model of $\mathrm{PHx}$ and portocaval transposition, once thought to be the result of flow stimulus, was in fact the result of redirecting the portal stimulants via the PCS to the systemic circulation and back to the liver via the vena cava inferior [32]. Further experiments in dogs with various degrees of splanchnic evisceration and $\mathrm{PHx}$ followed by portal infusion of insulin and/or glucagon confirmed the importance of insulin in the process of liver regeneration but also demonstrated that this hormone could not compensate for total evisceration [33]. This hormonal effect was also demonstrated in the liver after splanchnic evisceration and PCS and intraportal insulin infusion, preventing atrophy and glycogen depletion and promoting DNA synthesis [34].

With the importance of insulin for liver maintenance and regeneration firmly established, research evolved to screen for other potential hepatotrophic substances in the portal blood. Francavilla et al. [35] utilized a canine Eck fistula model in 1991, infusing $\mathrm{T}_{3}$, glucagon, prolactin, angiotensin II, vasopressin, norepinephrine, estradiol, IGF-II, HSS, TGF- $\alpha$, HGF (also termed hepatopoietin-A), EGF, TGF- $\beta$, tamoxifen, IL-1, IL-2 and insulin into one of the detached portal vein branches above the shunt [35]. Insulin and partly $\mathrm{T}_{3}$, IGF-II, HSS, TGF- $\alpha$ and HGF inhibited liver atrophy. The remaining substances were inert. Interestingly, TGF- $\beta$ increased atrophy, but this effect was reversed upon concomitant insulin infusion. This is an important study because it illustrates the importance of performing in vivo studies when studying a complex and integrated process such as liver regeneration: several of the above substances were found to enhance hepatocyte replication in in vitro studies (EGF [36], angiotensin II [37] and norepinephrine [38]) but they were not active when placed in context in a living, biological system, as was done in the above study. Certainly, cell culture models have their advantage in that one may study signaling pathways in individual cell lines without the confounding effects of different cell types, but the cross-talk between the extracellular matrix and different cell types in the liver parenchyma known to be particularly important to liver regeneration is missed [39]. This leaves us with the classic scientific paradox of the investigator changing the things he aims to observe by his act of intervention when utilizing the more 'mechanistic' model of cell culture. In contradistinction to this, animal models provide a more integrated and realistic means to study the highly coordinated process of liver regeneration.

Surgical Research on Liver Regeneration

\section{Quality versus Quantity - The Conflict between the Flow and Humoral Theories Approaches an End?}

Despite the numerous surgical models with splanchnic vascular manipulation and liver transplantation over a period of approximately 100 years implying the dominant role of humoral regulative mechanisms initiating liver regeneration and maintaining liver homeostasis, new studies appeared suggesting that increased sinusoidal flow after PHx could play a role after all. In the late 1990s, Sato et al. [40] and Niiya et al. [41] suggested that the acute portal hypertension and increased shear stress over the sinusoidal endothelial surface caused by $\mathrm{PHx}$ (and increased flow per gram remaining liver) triggered the regeneration cascade. In the same period, increased endothelial shear stress was found to modulate the endothelial production of nitric oxide and influence the hepatic vascular bed [42-44]. Later, liver regeneration after $\mathrm{PHx}$ in rats was shown to be inhibited by the administration of the $\mathrm{NO}$ antagonist $\mathrm{N}^{\mathrm{G}}$-nitro-L-arginine methyl ester, and restored by the NO donor 3-morpholinosydnonimine-1 $[45,46]$. This potential renaissance of the flow theory was challenged by Mortensen et al. [47] in a porcine model of PHx and gene expression analysis. By increasing the degree of liver resection (and consequently the rise in portal pressure and flow per gram remaining liver tissue) they observed a switch of the genetic response in the liver remnant from one of primarily cell cycle propagation (after 62\% PHx) to that of modulation of the intracellular redox status and the caspase cascade (after 75\% PHx) [47]. The different genetic response was proposed to be either due to the differences in sinusoidal pressure/shear stress and flow per gram remaining tissue, or due to differences in the amount of portal hepatotrophic substances delivered to the remnant. This was further investigated by constructing an aortoportal shunt from the aorta to the left portal vein, selectively increasing the flow to segments II, III and IV to the same flow levels as that seen after a $75 \% \mathrm{PHx}(2.89 \mathrm{ml} / \mathrm{g} / \mathrm{min})$. The investigators observed that these segments remained unchanged over 3 weeks, whilst the right side of the liver, receiving only portal blood in the same period, hypertrophied. The augmented flow seemed to inactivate the hyperperfused segments, as was reflected by the general down-regulation of transcriptional activity (according to microarray analysis). This suggested once more that increased flow in itself is not an adequate stimulus to trigger either hypertrophy or hyperplasia of the liver - the flow must be of splanchnic origin [48]. At the same time, the importance of the remnant perfusate quality (vs.

Eur Surg Res 2011;46:1-18 
quantity) was further illustrated by Ladurner et al. [49] who performed a 75\% $\mathrm{PHx}$ in pigs assigning one group to receive a side-to-side portosystemic $\mathrm{H}$ shunt decompressing the portal system. As expected, the portal vein flow (to the liver remnant) in the $\mathrm{H}$-shunt group was significantly lower than in animals without the shunt. However, the livers in both groups showed no differences in regenerative response, again providing evidence in support of the dominant stimulatory role of portal blood constituents.

To conclude, the flow theory seems again less credible although the optimal amount of portal and sinusoidal flow in the liver remnant seems to be undetermined. However, what is established is the damage caused by too much sinusoidal flow, as observed in the clinical scenarios of what has been termed SFSS [3]. Could it be that this syndrome is not only the result of the well-recognized sinusoidal congestion and endothelial damage, but also due to the lack of liver regeneration? If so, this would indirectly be an argument for the role of the flow theory. The observation of the fact that a graft weight/body weight ratio $<0.8 \%$ predisposes to SFSS has resulted in the assumption that portal hyperperfusion is the main culprit as the flow per gram liver tissue through the liver sinusoids increases to a harmful level. Evidence that this is the case is seen in preclinical large-animal models with portal vein decompression by portosystemic shunting in transplantation of small-for-size grafts [50-55] and in combined models of hepatectomy with marginal liver remnants and portosystemic shunting [56, 57]. Portal vein decompression, a normalization of the portal vein pressure and portal flow improves liver regeneration. This has been confirmed in clinical (human) studies [5861]. As a decrease in portal inflow results in a reciprocal increase in the hepatic artery flow due to the hepatic arterial buffer response [62], one could speculate that one of the reasons for the improved graft function and regeneration with portosystemic shunting is the increased oxygen tension in the regenerating liver, which brings us to the next topic.

\section{The Importance of the Oxygen/Energy Status in the Liver}

In a canine Eck fistula model in 1952, Cohn and Herrod [10] observed that arterialization of the portal vein stump over 4 months prevented liver atrophy. The oxygen tension in the hepatic veins was similar to control groups, indicating a pronounced oxygen extraction by the liver deprived of its portal blood supply. Consequent longterm canine experiments performed the next 10 years in animals with Eck fistula and portal vein stump arterialization showed that this altered hepatic vascularity was compatible with life, although many reported the development of vascular damage and liver fibrosis progressing to cirrhosis [11, 12, 14-16]. However, in 1954, Fisher et al. [13] did report superior liver regeneration after a $42 \%$ PHx in a dog model with Eck fistula and arterialization of the portal vein stump (controls regenerated to $80 \%$ of original volume vs. $103 \%$ in the arterialized group) and hypothesized that the increased oxygen delivery (and preserved flow) contributed to this difference. Furthermore, in 1967 Mito et al. [63] observed growth of a partial heterotopic homograft arterialized with an aortoportal shunt (grading the pressure in the shunt to $25-35 \mathrm{~mm} \mathrm{Hg}$ by a Teflon cuff) over a period of 16 days. Notably, this occurred despite the fact that the native liver received all the portal flow. In 1975, Horak et al. [64] also noted similar protective effects of PVA in Eck fistula dogs over a period of 10 weeks (also grading the arterial shunt flow with flow probes to equal flow in the portal vein before establishment of the Eck fistula) and, recently, Ott el al. [65] observed increased regeneration of the porcine liver remnant after PHx upon PVA compared to pigs with portal perfusion of the liver remnant. Not all investigators have reported beneficial effects of PVA though: in a study by Marchioro et al. [23], the arterialized side of the liver atrophied after 60 days in a canine model of split portocaval transposition and portal vein branch arterialization. This, however, occurred in conjunction with undisturbed portal flow to the contralateral side of the liver which hypertrophied, in effect, taking over the liver function (not unlike the 'parenchymal shift' described by Rous and Larimore 47 years earlier [17]).

In the clinical setting, PVA has been found useful in counteracting the portoprival state of the liver and hepatic encephalopathy in cirrhotic patients with Eck fistula $[66,67]$, but later experience with PVA of liver grafts has varied from being problematic due to histological changes in microsteatosis and fibrosis [68] to unproblematic in other series with good long-term liver function [69].

How can we explain the apparent beneficial shortterm effects of PVA on regeneration and liver homeostasis and what is relevant to research on liver regeneration? As obvious as it may seem, rodent models of PHx from the 1970s and canine models from the 1990s have shown that the capacity of the liver remnant to regenerate after $\mathrm{PHx}$ is dependent upon an increased supply of energy 
[70-72]. After PHx in rats, Yoshioka et al. [73] showed that oxygen supply to the liver increases by increased hepatic artery flow. Simultaneously, the hepatic oxygen extraction rate increases, while the total energy load decreases along with increased DNA synthesis. Arterialization of the liver remnant leads to improved survival in rats after extended hepatectomy [74-76], and this has also been shown to be beneficial in humans after extended hepatectomy [77]. While investigating the mechanisms behind SFSS, Smyrniotis et al. [78] studied the hemodynamic changes in differently sized liver grafts in pigs and disclosed that while the portal pressure and flow per gram liver increased inversely with graft size, hepatic artery flow decreased. However, the hepatic arterial buffer response was preserved, even showing an increased response with decreasing graft size. One could therefore hypothesize that a graded PVA could prove beneficial for the function and regeneration of the marginal liver remnant and the small-for-size liver graft, as arterialization potentially leads to an optimal oxidative status and energy charge in the hepatocytes. Accordingly, a surgical model of extended hepatectomy with arterialization of the functionally small and deficient remnant with observations of energy charge and histological signs of regeneration could cast light on this aspect and potentially be used as a bridge to complete regeneration in patients with small-for-size grafts. To avoid the deleterious effects of long-term arterialization in the patient, the end-to-side shunt should be embolized upon completed liver regeneration or normalization of liver function.

\section{The Liver as a Source of Growth Factors in Liver Regeneration}

The preceding sections have focused on how liver homeostasis and regeneration is influenced by the amount, pressure and the composition of its blood supply and drainage, but the liver itself is also a source of growth factors and cytokines which play a vital role in regeneration. In 1939, Brues et al. [79] found that a liver extract from adult and embryonic porcine liver would inhibit growth of cultured fibroblasts, with the process being reversible, suggesting that the liver was a source of growth inhibition. However, in 1952, Glinos and Gey [80] found the serum of $\mathrm{PHx}$ rats to exert a growth-promoting action on fibroblasts in tissue culture. Around the same time, $\mathrm{Bu}$ cher et al. [81] and Wenneker and Sussman [82] reported an increased number of mitoses in the non-hepatectomized partner in parabiotic rats with cross circulation indicating the presence of growth-stimulating factors in the effluent from the liver remnant $[81,82]$. This hypothesis was corroborated in in vivo rodent models by several investigators who observed increased liver cell mitosis in intact animals injected with serum from hepatectomized counterparts $[83,84]$. To circumvent the changes in portal hemodynamics caused by PHx, Sigel et al. [85] conducted canine experiments in the early 1960 s with autotransplanting of small liver grafts to the jejunal mesentery, later randomizing the animals to a $70 \% \mathrm{PHx}$ of the native liver. In contrast to control groups, the autografts in the animals with $70 \%$ PHx did not undergo atrophy, indicating again a growth stimulus from the resected liver to the autografts via the systemic circulation [85]. Similarly, in another experiment, autografts transplanted to the neck did not undergo atrophy, tentatively stimulated by the native liver manipulated with an Eck fistula (in contrast to animals without an Eck fistula) [86]. Thomford et al. [21] showed similar results in 1965 in dogs with heterotopic allografts, where the grafts did not suffer from atrophy when the native liver, receiving all the portal blood, was resected, again indicating a growth-stimulating effect from the liver effluent after PHx. Fourteen years later, Starzl et al. [87] extracted cytosol from hepatectomized canine livers ( 48 and $72 \mathrm{~h}$ after $\mathrm{PHx}$ ) injecting it into the portal vein stump of Eck fistula dogs and observed a proliferative response. A year later, it was observed that the growth-stimulating factor in the cytosol extract from regenerating canine livers (termed HSS) was organ specific in that it did not stimulate any glomerular proliferative activity when injected into the renal artery. Additionally, HSS was not found in liver extracts from animals that underwent splanchnic evisceration synchronously with $\mathrm{PHx}$, indicating that its synthesis in the liver probably was a result of splanchnic 'collaboration' [88]. Investigating how factors in the recipient liver influenced the action of HSS, Terblanche et al. [89] injected regenerative liver extract into the portal vein perfusing normal canine livers without any response. However, an augmented proliferative response was seen upon injecting the extract into the portal vein of the liver remnants 48 and $72 \mathrm{~h}$ after PHx. Further investigations of possible growth-stimulatory substances in the liver effluent from PHx pigs were performed by van Hoorn-Hickman et al. [90] in 1981 by cross circulation with recipient animals or exchange perfusion. Increased thymidine kinase activity and mitotic indices in biopsies from PCS (recipient) pigs corroborated Starzl's previous observations in dogs. Kahn et al. [91] also showed in 1982 that a stimulatory substance was transferred from a transplanted $\mathrm{PHx}$ liver 
to the host liver (which had PCS), stimulating a proliferative response in the latter (as judged by increased thymidine kinase activity and mitotic indices). The authors discussed whether this phenomenon could be clinically useful in aiding liver regeneration in the host liver in patients with liver failure treated by auxiliary liver grafting, leading to the question of whether the development of an acute or acute-upon-chronic liver failure in a large-animal model is useful to test the effect of injecting serum extracts of liver hepatotrophic substances from resected livers on the regeneration of damaged liver. Is it possible that infusion of a concentrate of the patients' own serum in the portal vein may assist in the regeneration of the remnant liver after an extensive liver resection and could a small-for-size graft procured from living donor splitliver grafting profit or in some way be supported by the stimulus that the serum of the donor could offer?

\section{What Has Happened the Last 2 Decades and Has It Helped Our Patients?}

During the last 20 years, the focus of research on liver regeneration after $\mathrm{PHx}$ has turned from examining extrinsic hepatic factors, such as portal and hepatic arterial blood flow and its content, to the intrinsic consequences these changes have in the extracellular matrix, the intracellular signal transduction mechanisms and genetic response in the liver. Studies in various cell culture models, stem cell transplantation, microarray analysis in rodent and porcine models, the impact of the immune system, blood platelets and serotonin, the complement system, cytokines and the interaction between the many different cell types now known to regulate the regenerative process have all unquestionably added much knowledge to the research on liver regeneration. However, at the same time, these studies have made the picture complex and seemingly increasingly intangible when it comes to the clinical application of the knowledge gained.

Although this review comprises traditional surgical animal models, novel genetic engineering with rodent knockout models warrants mention because this area of research will most likely become increasingly dominant in future investigations of liver regeneration (table 3). This technique is unquestionably very powerful, in a deterministic sense, and has illuminated the roles of several important genes and gene products concerned with the priming of hepatocytes (IL-6, TNF, C3a, C5a, MyD88 and TIMP3), extracellular matrix remodeling (uPA, MT and MMP9), intracellular signal transduction (C/EBP- $\beta$,
IGFBP-1, HB-EGF, OSM, TGF- $\alpha$, Met and caveolin-1), lipid metabolism (PPAR- $\alpha$ ) and termination of liver regeneration (TGF- $\beta$ ). The challenge, on a larger scale, however, lies in linking all the bits of information together.

Extensive reviews of the vast amount of more contemporary published literature on the molecular control of liver regeneration in the past 20-30 years have been written by authorities on liver research and require mention here. In 2004, Taub [92] outlined the 'cytokine' and 'growth-factor' pathways eventually leading to the activation of downstream intracellular signaling substances promoting cell cycle entry and mitosis, and the (relatively few number of) molecules arresting liver growth, maintaining a constant liver/body mass. The review concludes that what remains unclear is how the size of the liver is determined, 'how the known molecular pathways necessary for liver regeneration are altered in human disease', and that 'greater insight will be required to develop improved pharmacological therapeutics and surgical approaches'. There is no mention of any clinical application of the knowledge gained so far [92]. In 2006, Fausto et al. [93] reviewed research in liver regeneration and also described the 'cytokine' and 'growth-factor' pathways and their interaction and, additionally, the influence of metabolic stimuli in regeneration. They concluded that the study of liver regeneration affords a unique model to study signal transduction mechanisms and cell cycle events and emphasized the importance of understanding the process of liver regeneration for the appropriate management of acute liver failure and liver cirrhosis. They added that what is needed is a more 'rigorous effort to apply the knowledge gained in experimental work to solve clinical problems'. However, the review does not mention if and how all this scientific work has resulted in a single therapeutic procedure [93]. In his published Rous-Whipple Award Lecture from 2010, Michalapoulos [39] summarized the control of liver regeneration by the so-called 'complete mitogens' that are mitogenic in hepatocyte cell cultures (HGF and receptor c-MET and ligands of the EGF, TGF- $\alpha$, HB-EGF and AR), and by 'auxiliary mitogens', the ablation of which delay the regeneration process (amongst others, norepinephrine, TNF, IL-6, VEGF, bile acids, serotonin, complement proteins, leptin, FGF-1, FGF-2 and insulin). A redundancy exists in all these different pathways as there seems to be a considerable overlap between the many signaling cascades - blockage of one route is compensated by another, leading to completion of liver regeneration. In this comprehensive review, the author concludes that 'liver failure, essentially a fail- 
Table 3. Chronological summary of transgenic models of liver regeneration

\begin{tabular}{|c|c|c|c|}
\hline Year & Gene product & Study title and brief description of the study & Reference \\
\hline 1994 & TGF- $\alpha$ & $\begin{array}{l}\text { 'Overexpression of transforming growth factor-alpha causes liver enlargement and } \\
\text { increased hepatocyte proliferation in transgenic mice'. TGF- } \alpha \text { stimulates hepatocyte } \\
\text { DNA replication. }\end{array}$ & 114 \\
\hline 1996 & IL-6 & $\begin{array}{l}\text { 'Liver failure and defective hepatocyte regeneration in interleukin-6-deficient mice'. The } \\
\text { role of IL- } 6 \text { in priming quiescent hepatocytes in the G0 phase is illustrated. }\end{array}$ & 99 \\
\hline 1997 & TNF & $\begin{array}{l}\text { 'Initiation of liver growth by tumor necrosis factor: deficient liver regeneration in mice } \\
\text { lacking type I tumor necrosis factor receptor'. The role of TNF in priming quiescent } \\
\text { hepatocytes in the G0 phase is determined. }\end{array}$ & 115 \\
\hline 1998 & iNOS & $\begin{array}{l}\text { 'Impaired liver regeneration in inducible nitric oxide synthase-deficient mice'. The } \\
\text { protective role of nitric oxide against cytokine injury during regeneration is reported. }\end{array}$ & 116 \\
\hline 1998 & $\mathrm{C} / \mathrm{EBP}-\beta$ & $\begin{array}{l}\text { 'CCAAT enhancer-binding protein beta is required for normal hepatocyte proliferation in } \\
\text { mice after partial hepatectomy'. C/EBP- } \beta \text { is a transcription factor activating several genes } \\
\text { important in the acute-phase response and early stages of liver regeneration. }\end{array}$ & 117 \\
\hline 1998 & uPA & $\begin{array}{l}\text { 'Liver regeneration is transiently impaired in urokinase-deficient mice'. uPA is important } \\
\text { in initial phases of regeneration as it activates dormant HGF in liver remnant matrix } \\
\text { immediately after resection. }\end{array}$ & 118 \\
\hline 2002 & PPAR- $\alpha$ & $\begin{array}{l}\text { 'Delayed liver regeneration in peroxisome proliferator-activated receptor-alpha-null mice'. } \\
\text { The importance of the regulation of lipid turnover during liver regeneration is illustrated. }\end{array}$ & 119 \\
\hline 2003 & $\mathrm{C} 3 \mathrm{a} / \mathrm{C} 5 \mathrm{a}$ & $\begin{array}{l}\text { 'The proinflammatory mediators C3a and C5a are essential for liver regeneration'. } \\
\text { Complement factors are implicated in early phases of regeneration as knockout mice for } \\
\text { C3a and C5a have impaired production of TNF and IL- } 6 \text { after resection. }\end{array}$ & 120 \\
\hline 2003 & IGFBP-1 & $\begin{array}{l}\text { 'Impaired hepatocyte DNA synthetic response posthepatectomy in insulin-like growth } \\
\text { factor binding protein 1-deficient mice with defects in C/EBP beta and mitogen-activated } \\
\text { protein kinase/extracellular signal-regulated kinase regulation'. }\end{array}$ & 121 \\
\hline 2004 & TIMP3 & $\begin{array}{l}\text { 'Abnormal TNF activity in Timp3 }(-/-) \text { mice leads to chronic hepatic inflammation and } \\
\text { failure of liver regeneration'. In a liver regeneration model that requires TNF signaling, } \\
\text { Timp3(-/-) mice succumbed to liver failure. These data indicate that TIMP3 is a crucial } \\
\text { innate negative regulator of TNF. }\end{array}$ & 122 \\
\hline 2004 & Met & $\begin{array}{l}\text { 'Met provides essential signals for liver regeneration'. This study demonstrates that the } \\
\text { HGF/scatter factor/Met signaling system is essential for cell cycle entry after partial } \\
\text { hepatectomy. }\end{array}$ & 123 \\
\hline 2004 & OSM & $\begin{array}{l}\text { 'Hepatocyte proliferation and tissue remodeling is impaired after liver injury in oncostatin } \\
\text { M receptor knockout mice'. OSM signaling is required for hepatocyte proliferation and } \\
\text { tissue remodeling during liver regeneration. OSM is also a key mediator of IL-6 in liver } \\
\text { regeneration. }\end{array}$ & 106 \\
\hline 2004 & TGF- $\beta$ & $\begin{array}{l}\text { 'Intact signaling by transforming growth factor beta is not required for termination of liver } \\
\text { regeneration in mice'. TGF- } \beta \text { inhibits regeneration in early phases of regeneration but is } \\
\text { not solely responsible for the termination of liver regeneration. }\end{array}$ & 124 \\
\hline 2005 & HB-EGF & $\begin{array}{l}\text { 'Heparin-binding epidermal growth factor-like growth factor links hepatocyte priming with } \\
\text { cell cycle progression during liver regeneration'. DNA replication after partial hepatectomy } \\
\text { is delayed in HB-EGF knockout mice. }\end{array}$ & 125 \\
\hline 2005 & MT & $\begin{array}{l}\text { 'Impaired hepatic regeneration in metallothionein-I/II knockout mice'. The importance of } \\
\text { matrix remodeling during liver regeneration is discussed. }\end{array}$ & 126 \\
\hline 2005 & MyD88 & $\begin{array}{l}\text { 'Contribution of Toll-like receptor/myeloid differentiation factor } 88 \text { signaling to murine } \\
\text { liver regeneration'. Bacterial endotoxin (lipopolysaccharide) induced production of } \\
\text { TNF (e.g. TNF- } \alpha \text { ) is deficient in MyD88 null mice (lipopolysaccharide is also a primer for } \\
\text { hepatocytes in the G0 phase). }\end{array}$ & 127 \\
\hline 2006 & MMP9 & $\begin{array}{l}\text { 'Matrix metalloproteinase- } 9 \text { is an important factor in hepatic regeneration after partial } \\
\text { hepatectomy in mice'. The importance of matrix remodeling during regeneration is illustrated. }\end{array}$ & 128 \\
\hline 2006 & Caveolin-1 & $\begin{array}{l}\text { 'Caveolin-1 is essential for liver regeneration'. Caveolin- } 1 \text { plays a crucial role in the } \\
\text { mechanisms that coordinate lipid metabolism with the proliferative response occurring in } \\
\text { the liver after cellular injury. }\end{array}$ & 129 \\
\hline 2007 & Caveolin-1 & $\begin{array}{l}\text { 'Dispensability and dynamics of caveolin-1 during liver regeneration and in isolated hepatic } \\
\text { cells'. Caveolin is important but not essential for regeneration. }\end{array}$ & 130 \\
\hline
\end{tabular}


ure of regeneration, should be subject to mechanistic analysis based on knowledge already gained on regeneration, and perhaps therapeutic interventions may be designed with impact on human liver disease' [39]. Hence it seems clear that the authors are aware of the gap between basic laboratory investigation and clinical appliance in this field.

\section{The Benefits of 133 Years of Surgical Research on Liver Regeneration}

How then has research on liver regeneration in the past 133 years benefited the patient with liver cirrhosis, acute liver failure or liver metastasis? The recognition of the importance of portal blood to liver homeostasis and regeneration was obviously crucial to the pioneers of liver transplantation as they observed how the auxiliary graft would undergo atrophy without portal blood constituent stimulus [18]. The earlier canine and porcine PVA experiments [10-14, 63-65] also illustrated to the transplantation surgeon that the auxiliary graft could be perfused by PVA as an option to leave the hilus of the native liver untouched and also in cases of portal vein thrombosis [94-97]. Could PVA of the small-for-size graft be an option in the future to avoid the small-for-size syndrome?

Furthermore, as part of the emerging multimodal three-stage treatment of colorectal metastases [2], surgeons may now embolize the portal vein before performing large resections in order to stimulate liver hyperplasia in the remnant to be. By this, one may avoid postoperative liver failure, acknowledging that diverting portal flow away from one side to the other results in the 'parenchymal shift' described by Rous and Larimore [17] in 1920.

\section{Conclusion}

The surgical principles and practice of preoperative portal vein embolization to induce hyperplasia of the remnant liver after $\mathrm{PHx}$, and portal vein decompression by portosystemic shunting to reduce sinusoidal congestion in the case of SFSS after liver transplantation are well established. Apart from these, there are no novel patient therapies available to aid and augment the process of liver regeneration after extended liver resections, toxic liver insults or in the cirrhotic patient. This is in spite of all the modern technological advances and the knowledge gained on the microscopic and molecular aspects of liver regeneration in the past $20-30$ years. We suggest that it is time to turn back to the systemic large-animal surgical research on liver regeneration as it offers a more integrated, systemic biological understanding of this complex process, and that a more clinically relevant progression could possibly be made with a closer collaboration between the hepatologist, liver surgeon/transplant surgeon and the laboratory scientist.

\section{Disclosure Statement}

The authors have no conflict of interest.

\section{References}

1 Pichlmayr R, Ringe B, Gubernatis G, Hauss J, Bunzendahl H: Transplantation of a donor liver to 2 recipients (splitting transplantation) - a new method in the further development of segmental liver transplantation (in German). Langenbecks Arch Chir 1988;373: 127-130.

2 Gonzalez HD, Figueras J: Practical questions in liver metastases of colorectal cancer: general principles of treatment. HPB (Oxford) 2007;9:251-258.

3 Dahm F, Georgiev P, Clavien PA: Small-forsize syndrome after partial liver transplantation: definition, mechanisms of disease and clinical implications. Am J Transplant 2005; 5:2605-2610
4 Khan AZ, Morris-Stiff G, Makuuchi M: Patterns of chemotherapy-induced hepatic injury and their implications for patients undergoing liver resection for colorectal liver metastases. J Hepatobiliary Pancreat Surg 2009;16:137-144.

5 Sen S, Jalan R: The role of the molecular adsorbents recirculating system (MARS) in the management of liver failure. Perfusion 2004; 19(suppl 1):S43-S48.

6 Eck NVK: Concerning ligation of the vena porta (in Russian). Voen Med Zh 1877;130 (English translation: Child CG: Eck's fistula. Surg Gynecol Obstet 1953;96:375-376).

7 Hahn M, Massen O, Nencki M, Pavlov J: Die Eck'sche Fistel zwischen der unteren Hohlvene und der Pfortader und Folgen für den Organismus. Arch Exp Pathol Pharmakol 189;32:161-210.
8 Grindlay JH, Bollman JL: Regeneration of the liver in the dog after partial hepatectomy: role of the venous circulation. Surg Gynecol Obstet 1952;94:491-496.

>9 Child CG III, Barr D, Holswade GR, Harrison CS: Liver regeneration following portacaval transposition in dogs. Ann Surg 1953; 138:600-608.

$>10$ Cohn R, Herrod C: Some effects upon the liver of complete arterialization of its blood supply. Surgery 1952;32:214-218.

-11 McCredie JA, Doggart JR, Welbourn RB: Total arterialization of the liver. Br J Surg 1957; 45:83-100.

12 Schilling JA, McKee FW: Late follow-up on experimental hepatic-portal arteriovenous fistulae. Surg Forum 1953;4:392-397. 
13 Fisher B, Russ C, Updegraff H, Fisher ER: Effect of increased hepatic blood flow upon liver regeneration. AMA Arch Surg 1954;69: 263-272.

14 Rather LJ, Cohn R: Some effects upon the liver of complete arterialization of its blood supply. III. Acute vascular necrosis (in undetermined language). Surgery 1953;34:207210.

15 Schwartz SI, Morton JH, McGovern GR: Experimental arterialization of the liver. Surgery 1961;49:611-617.

- 16 Zuidema GD, Gaisford WD, Abell MR, Brody TM, Neill SA, Child CG: Segmental portal arterialization of canine liver. Surgery 1963; 53:689-698.

17 Rous P, Larimore LD: Relation of the portal blood to liver maintenance: a demonstration of liver atrophy conditional on compensation. J Exp Med 1920;31:609-632.

18 Starzl TE, Marchioro TL, Rowlands DT Jr, Kirkpatrick CH, Wilson WE, Rifkind D, et al: Immunosuppression after experimental and clinical homotransplantation of the liver. Ann Surg 1964;160:411-439.

- 19 Marchioro TL, Porter KA, Brown BI, Faris TD, Herrmann TJ, Sudweeks A, et al: The specific influence of nonhepatic splanchnic venous blood flow on the liver. Surg Forum 1965; 16:280-282.

-20 Tretbar LL, Beven EG, Hermann RE: Homotransplantation of an auxiliary dog liver into the pelvis: effect of protacaval shunt in the prevention of liver atrophy. Surg Forum 1965;16:219-221.

-21 Thomford NR, Shorter RG, Hallenbeck GA: Homotransplantation of the canine liver: survival and histology with and without azathioprine. Arch Surg 1965;90:527-538.

-22 Halgrimson CG, Marchioro TL, Faris TD, Porter KA, Peters GN, Starzl TE: Auxiliary liver transplantation: effect of host portacaval shunt. Experimental and clinical observations. Arch Surg 1966;93:107-118.

-23 Marchioro TL, Porter KA, Brown BI, Otte JB, Starzl TE: The effect of partial portacaval transposition on the canine liver. Surgery 1967;61:723-732.

-24 Marchioro TL, Porter KA, Dickinson TC, Faris TD, Starzi TE: Physiologic requirements for auxiliary liver homotransplantation. Surg Gynecol Obstet 1965;121:17-31.

-25 Price JB Jr, Takeshige K, Parsa M, Voorhees AB Jr: Characteristics of animals maintained without splanchnic portal organs. Surgery 1971;70:768-777.

26 Price JB Jr, Takeshige K, Max MH, Voorhees AB Jr: Glucagon as the portal factor modifying hepatic regeneration. Surgery 1972;72: 74-82.

-27 Starzl TE, Francavilla A, Halgrimson CG, Francavilla FR, Porter KA, Brown TH, et al: The origin, hormonal nature, and action of hepatotrophic substances in portal venous blood. Surg Gynecol Obstet 1973;137:179199.
28 Starzl TE, Porter KA, Putnam CW: Intraportal insulin protects from the liver injury of portacavalshuntindogs. Lancet 1975;ii:12411242.

29 Starzl TE, Porter KA, Kashiwagi N: Portal hepatotrophic factors, diabetes mellitus and acute liver atrophy, hypertrophy and regeneration. Surg Gynecol Obstet 1975;141:843858.

30 Starzl TE, Watanabe K, Porter KA, Putnam CW: Effects of insulin, glucagon, and insulin/glucagon infusions on liver morphology and cell division after complete portacaval shunt in dogs. Lancet 1976;i:821-825.

31 Duguay LR, Orloff MJ: Role of the pancreas in regulation of liver regeneration in dogs. Surg Forum 1977;28:387-390.

-32 Starzl TE, Porter KA, Francavilla JA, Benichou J, Putnam CW: A hundred years of the hepatotrophic controversy. Ciba Found Symp 1977;111-129.

33 Starzl TE, Francavilla A, Porter KA, Benichou J: The effect upon the liver of evisceration with or without hormone replacement. Surg Gynecol Obstet 1978;146:524-532.

-34 Starzl TE, Francavilla A, Porter KA, Benichou J, Jones AF: The effect of splanchnic viscera removal upon canine liver regeneration. Surg Gynecol Obstet 1978;147:193-207.

- 35 Francavilla A, Starzl TE, Porter K, Foglieni CS, Michalopoulos GK, Carrieri G, et al: Screening for candidate hepatic growth factors by selective portal infusion after canine Eck's fistula. Hepatology 1991;14:665-670.

-36 Richman RA, Claus TH, Pilkis SJ, Friedman DL: Hormonal stimulation of DNA synthesis in primary cultures of adult rat hepatocytes. Proc Natl Acad Sci USA 1976;73:3589-3593.

37 Carr BI: Gene expression and mitogenic response of rat hepatocytes to EGF, TGF alpha and angiotensinogen gene products. Proc Am Assoc Can Res 1990;31:1332.

-38 Cruise JL, Houck KA, Michalopoulos GK: Induction of DNA synthesis in cultured rat hepatocytes through stimulation of alpha 1 adrenoreceptor by norepinephrine. Science 1985;227:749-751

39 Michalopoulos GK: Liver regeneration after partial hepatectomy: critical analysis of mechanistic dilemmas. Am J Pathol 2010; 176:2-13.

40 Sato Y, Koyama S, Tsukada K, Hatakeyama $\mathrm{K}$ : Acute portal hypertension reflecting shear stress as a trigger of liver regeneration following partial hepatectomy. Surg Today 1997;27:518-526.

41 Niiya T, Murakami M, Aoki T, Murai N, Shimizu Y, Kusano M: Immediate increase of portal pressure, reflecting sinusoidal shear stress, induced liver regeneration after partial hepatectomy. J Hepatobiliary Pancreat Surg 1999;6:275-280.
42 Hermann C, Zeiher AM, Dimmeler S: Shear stress inhibits $\mathrm{H}_{2} \mathrm{O}_{2}$-induced apoptosis of human endothelial cells by modulation of the glutathione redox cycle and nitric oxide synthase. Arterioscler Thromb Vasc Biol 1997; 17:3588-3592.

43 Macedo MP, Lautt WW: Shear-induced modulation of vasoconstriction in the hepatic artery and portal vein by nitric oxide. Am J Physiol 1998;274:G253-G260.

44 Wang HH, Lautt WW: Evidence of nitric oxide, a flow-dependent factor, being a trigger of liver regeneration in rats. Can J Physiol Pharmacol 1998;76:1072-1079.

45 Schoen JM, Wang HH, Minuk GY, Lautt WW: Shear stress-induced nitric oxide release triggers the liver regeneration cascade. Nitric Oxide 2001;5:453-464.

46 Schoen JM, Lautt WW: Nitric oxide potentiates C-Fos mRNA expression after $2 / 3$ partial hepatectomy. Proc West Pharmacol Soc 2002; $45: 47-48$

47 Mortensen KE, Conley LN, Hedegaard J, Kalstad T, Sorensen P, Bendixen C, et al: Regenerative response in the pig liver remnant varies with the degree of resection and rise in portal pressure. Am J Physiol Gastrointest Liver Physiol 2008;294:G819-G830.

48 Mortensen KE: Increased sinusoidal flow is not the primary stimulus to liver regeneration. Comp Hepatol 2010;9:2.

49 Ladurner R, Traub F, Schenk M, Konigsrainer A, Glatzle J: Cellular liver regeneration after extended hepatic resection in pigs. HPB Surg 2009;2009:306740.

50 Asakura T, Ohkohchi N, Orii T, Koyamada $\mathrm{N}$, Tsukamoto S, Sato M, et al: Portal vein pressure is the key for successful liver transplantation of an extremely small graft in the pig model. Transpl Int 2003;16:376-382.

51 Kelly DM, Demetris AJ, Fung JJ, Marcos A, Zhu Y, Subbotin V, et al: Porcine partial liver transplantation: a novel model of the 'smallfor-size' liver graft. Liver Transpl 2004;10: 253-263.

$52 \mathrm{Ku} \mathrm{Y,} \mathrm{Fukumoto} \mathrm{T,} \mathrm{Nishida} \mathrm{T,} \mathrm{Tominaga} \mathrm{M,}$ Maeda I, Kitagawa T, et al: Evidence that portal vein decompression improves survival of canine quarter orthotopic liver transplantation. Transplantation 1995;59:1388-1392.

53 Pouyet M, Paquet C, Mechet I, Le Derf Y, Bernard P, Figueiredo P, et al: Hemodynamic tolerance and rapid hypertrophy of a hepatic graft corresponding to less than $30 \%$ of the ideal mass in pigs (in French). Gastroenterol Clin Biol 2001;25:869-874.

54 Smyrniotis VE, Kostopanagiotou G, Theodoraki K, Gamaletsos E, Kondi-Pafiti A, Mystakidou K, et al: Effect of mesocaval shunt on survival of small-for-size liver grafts: experimental study in pigs. Transplantation 2003, 75:1737-1740.

55 Wang HS, Ohkohchi N, Enomoto Y, Usuda M, Miyagi S, Asakura T, et al: Excessive portal flow causes graft failure in extremely small-for-size liver transplantation in pigs. World J Gastroenterol 2005;11:6954-6959. 
56 Iida T, Yagi S, Taniguchi K, Hori T, Uemoto $S$ : Improvement of morphological changes after $70 \%$ hepatectomy with portocaval shunt: preclinical study in porcine model. J Surg Res 2007;143:238-246.

- 57 Ueno S, Kobayashi Y, Kurita K, Tanabe G, Aikou T: Effect of prior portosystemic shunt on early hepatic hemodynamics and sinusoids following $84 \%$ hepatectomy in dogs. Res Exp Med (Berl) 1995;195:1-8.

58 Lo CM, Liu CL, Fan ST: Portal hyperperfusion injury as the cause of primary nonfunction in a small-for-size liver graft - successful treatment with splenic artery ligation. Liver Transpl 2003;9:626-628.

- 59 Troisi R, Ricciardi S, Smeets P, Petrovic M Van Maele G, Colle I, et al: Effects of hemiportocaval shunts for inflow modulation on the outcome of small-for-size grafts in living donor liver transplantation. Am J Transplant 2005;5:1397-1404

- 60 Umeda Y, Yagi T, Sadamori H, Matsukawa $\mathrm{H}$, Matsuda $\mathrm{H}$, Shinoura S, et al: Effects of prophylactic splenic artery modulation on portal overperfusion and liver regeneration in small-for-size graft. Transplantation 2008;86:673-680.

-61 Yoshizumi T, Taketomi A, Soejima Y, Ikegami T, Uchiyama H, Kayashima H, et al: The beneficial role of simultaneous splenectomy in living donor liver transplantation in patients with small-for-size graft. Transpl Int 2008;21:833-842.

-62 Lautt WW: Mechanism and role of intrinsic regulation of hepatic arterial blood flow: hepatic arterial buffer response. Am J Physiol 1985;249:G549-G556.

63 Mito M, Ackroyd FW, Covelli VH, Eyskens E, Katayama I, McDermott WV Jr: Partial heterotopic liver homograft in dogs utilizing portal arterialization. Ann Surg 1967;165: 20-32.

-64 Horak W, Gangl A, Funovics J, Grabner G: Effect of portacaval shunt and arterialization of the liver on bile acid metabolism. Gastroenterology 1975;69:338-341.

65 Ott R, Schuppan D, Tannapfel A, Wittekind C, Erhardt W, Henke J, et al: Portal vein arterialisation as a technical option in liver transplantation: impact on function, regeneration, and morphology of the liver following hemihepatectomy in pigs. Liver Int 2003; 23:54-62.

-66 Adamsons RJ, Kinkhabwala M, Moskowitz H, Himmelfarb E, Minkowitz S, Lerner B: Portacaval shunt with arterialization of the hepatic portion of the portal vein. Surg Gynecol Obstet 1972;135:529-535.

-67 Maillard JN, Rueff B, Prandi D, Sicot C: Hepatic arterialization and portacaval shunt in hepatic cirrhosis. An assessment. Arch Surg 1974;108:315-320.

-68 Charco R, Margarit C, Lopez-Talavera JC, Hidalgo E, Castells L, Allende H, et al: Outcome and hepatic hemodynamics in liver transplant patients with portal vein arterialization. Am J Transplant 2001;1:146-151.
69 Erhard J, Lange R, Giebler R, Rauen U, de Groot H, Eigler FW: Arterialization of the portal vein in orthotopic and auxiliary liver transplantation. A report of three cases. Transplantation 1995;60:877-879.

70 Nonami T, Asahi K, Harada A, Nakao A, Takagi H: Effect of hyperdynamic circulatory support on hepatic hemodynamics, oxygen supply and demand after massive hepatectomy. Surgery 1991;109:277-283.

71 Ozawa K, Takeda H, Yamaoka Y, Nambu H, Kamiyama Y: Adenine nucleotide metabolism in regenerative, atrophic, and necrotizing processes of the liver. Gastroenterology 1974;67:1225-1230.

72 Yamaoka Y, Ohsawa T, Takasan H, Ozawa K: Energy requirement in regenerative and atrophic processes of the liver in man and other mammals. Surg Gynecol Obstet 1974; 139:234-240.

73 Yoshioka S, Miyazaki M, Shimizu H, Ito H, Nakagawa K, Ambiru S, et al: Hepatic venous hemoglobin oxygen saturation predicts regenerative status of remnant liver after partial hepatectomy in rats. Hepatology 1998; 27:1349-1353.

-74 Shimizu Y, Miyazaki M, Shimizu H, Ito H, Nakagawa K, Ambiru S, et al: Beneficial effects of arterialization of the portal vein on extended hepatectomy. Br J Surg 2000;87: 784-789.

75 Fan YD, Praet M, Van Huysse J, Lelie B, de Hemptinne B: Effects of portal vein arterialization on liver regeneration after partial hepatectomy in the rat. Liver Transpl 2002;8: 146-152.

76 Nardo B, Puviani L, Caraceni P, Pacile V, Bertelli R, Beltempo P, et al: Portal vein arterialization for the treatment of post resection acute liver failure in the rat. Transplant Proc 2006;38:1185-1186

77 Iseki J, Touyama K, Noie T, Nakagami K, Takagi M, Hakamada K, et al: Partial portal arterialization for the prevention of massive liver necrosis following extended pancreatobiliary surgery: experience of two cases. Surg Today 1992;22:568-571.

78 Smyrniotis V, Kostopanagiotou G, Kondi A, Gamaletsos E, Theodoraki K, Kehagias D, et al: Hemodynamic interaction between portal vein and hepatic artery flow in small-forsize split liver transplantation. Transpl Int 2002;15:355-360.

79 Brues AM, Subbarow Y, Jackson EB, Aub JC: Growth inhibition by substances in liver. J Exp Med 1940;71:423-438.

80 Glinos AD, Gey GO: Humoral factors involved in the induction of liver regeneration in the rat. Proc Soc Exp Biol Med 1952;80: 421-425.

81 Bucher NL, Scott JF, Aub JC: Regeneration of the liver in parabiotic rats. Cancer Res 1951; 11:457-465.

82 Wenneker AS, Sussman N: Regeneration of liver tissue following partial hepatectomy in parabiotic rats. Proc Soc Exp Biol Med 1951; 76:683-686.
83 Paschkis KE, Goddard J, Cantarow A, Adibi $S$ : Stimulation of growth by partial hepatectomy. Proc Soc Exp Biol Med 1959;101:184186.

84 Zimmerman M, Cellozzi E: Stimulation of cell division in normal rat liver by a factor in serum from hepatectomized rats. Fed Proc 1960;19:139.

85 Sigel B, Acevedo FJ, Dunn MR: The effect of partial hepatectomy on autotransplanted liver tissue. Surg Gynecol Obstet 1963;117:2936.

86 Sigel B, Baldia L, Dunn MR: Studies of liver lobes autotransplanted outside the abdominal cavity. Surg Gynecol Obstet 1967;124: 525-530.

87 Starzl TE, Jones AF, Terblanche J, Usui S, Porter KA, Mazzoni G: Growth-stimulating factor in regenerating canine liver. Lancet 1979;i:127-130.

88 Starzl TE, Porter KA, Hayashida N, Schechter P, Terblanche J: Further studies on hepatic stimulatory substance (SS) after partial hepatectomy. J Surg Res 1980;29:471-474.

-89 Terblanche J, Porter KA, Starzl TE, Moore J, Patzelt L, Hayashida N: Stimulation of hepatic regeneration after partial hepatectomy by infusion of a cytosol extract from regenerating dog liver. Surg Gynecol Obstet 1980; 151:538-544.

-90 van Hoorn-Hickman R, Kahn D, Green J, MacLeod HA, Terblanche J: Is there a regeneration stimulator substance in the effluent from perfused partially hepatectomized livers? Hepatology 1981;1:287-293.

-91 Kahn D, van Hoorn-Hickman R, McLeod H, Terblanche J: The stimulatory effect of a partially hepatectomized auxiliary graft upon the host liver. Observations on the regenerative response in orthotopic and heterotopic grafts. S Afr Med J 1982;61:362-365.

92 Taub R: Liver regeneration: from myth to mechanism. Nat Rev Mol Cell Biol 2004;5: 836-847.

93 Fausto N, Campbell JS, Riehle KJ: Liver regeneration. Hepatology 2006;43:S45-S53.

94 Margarit C, Bilbao I, Charco R, Lazaro JL, Hidalgo E, Allende E, et al: Auxiliary heterotopic liver transplantation with portal vein arterialization for fulminant hepatic failure. Liver Transpl 2000;6:805-809.

$>95$ Erhard J, Lange R, Rauen U, Scherer R, Friedrich J, Pietsch M, et al: Auxiliary liver transplantation with arterialization of the portal vein for acute hepatic failure. Transpl Int 1998:11:266-271.

96 Lange R, Rauen U, Janssen H, Erhard J, de Groot $\mathrm{H}$ : Temporary heterotopic auxiliary liver transplantation with arterialization of the portal vein as treatment of acute liver failure. Transpl Int 2007;20:473-474.

-97 Tsivian M, Neri F, Prezzi D, Puviani L, Pacile V, Bertelli R, et al: Portal vein arterialization in hepatobiliary surgery and liver transplantation. Transplant Proc 2007;39:1877-1878. 
-98 Webber EM, Bruix J, Pierce RH, Fausto N: Tumor necrosis factor primes hepatocytes for DNA replication in the rat. Hepatology 1998;28:1226-1234.

-99 Cressman DE, Greenbaum LE, DeAngelis RA, Ciliberto G, Furth EE, Poli V, et al: Liver failure and defective hepatocyte regeneration in interleukin-6-deficient mice. Science 1996;274:1379-1383.

-100 Michalopoulos G, Houck KA, Dolan ML, Leutteke NC: Control of hepatocyte replication by two serum factors. Cancer Res 1984;44:4414-4419.

101 Mead JE, Fausto N: Transforming growth factor alpha may be a physiological regulator of liver regeneration by means of an autocrine mechanism. Proc Natl Acad Sci USA 1989;86:1558-1562.

-102 Bucher NL, Patel U, Cohen S: Hormonal factors concerned with liver regeneration. Ciba Found Symp 1977;55:95-107.

- 103 Berasain C, Garcia-Trevijano ER, Castillo J, Erroba E, Lee DC, Prieto J, et al: Amphiregulin: an early trigger of liver regeneration in mice. Gastroenterology 2005;128: 424-432.

104 Kiso S, Kawata S, Tamura S, Higashiyama S, Ito N, Tsushima H, et al: Role of heparinbinding epidermal growth factor-like growth factor as a hepatotrophic factor in rat liver regeneration after partial hepatectomy. Hepatology 1995;22:1584-1590.

-105 Ren X, Hogaboam C, Carpenter A, Colletti L: Stem cell factor restores hepatocyte proliferation in IL-6 knockout mice following $70 \%$ hepatectomy. J Clin Invest 2003;112: 1407-1418.

-106 Nakamura K, Nonaka H, Saito H, Tanaka M, Miyajima A: Hepatocyte proliferation and tissue remodeling is impaired after liver injury in oncostatin $\mathrm{M}$ receptor knockout mice. Hepatology 2004;39:635-644.

-107 Huang W, Ma K, Zhang J, Qatanani M, Cuvillier J, Liu J, et al: Nuclear receptor-dependent bile acid signaling is required for normal liver regeneration. Science 2006; 312:233-236.

-108 Lesurtel M, Graf R, Aleil B, Walther DJ, Tian Y, Jochum W, et al: Platelet-derived serotonin mediates liver regeneration. Science 2006;312:104-107.

-109 LeCouter J, Moritz DR, Li B, Phillips GL, Liang XH, Gerber HP, et al: Angiogenesisindependent endothelial protection of liver: role of VEGFR-1. Science 2003;299:890893.

-110 Kitagawa T, Yokoyama Y, Kokuryo T, Kawai T, Watanabe K, Kawai K, et al: Estrogen promotes hepatic regeneration via activating serotonin signal. Shock 2009;31: 615-620.

-111 Kogure K, Omata W, Kanzaki M, Zhang YQ, Yasuda H, Mine T, et al: A single intraportal administration of follistatin accelerates liver regeneration in partially hepatectomized rats. Gastroenterology 1995;108: 1136-1142.
112 Russell WE, Coffey RJ Jr, Ouellette AJ, Moses HL: Type beta transforming growth factor reversibly inhibits the early proliferative response to partial hepatectomy in the rat. Proc Natl Acad Sci USA 1988;85:51265130.

113 Ho J, de Guise C, Kim C, Lemay S, Wang XF, Lebrun JJ: Activin induces hepatocyte cell growth arrest through induction of the cyclin-dependent kinase inhibitor p15INK4B and Sp1. Cell Signal 2004;16: 693-701.

$>114$ Webber EM, Wu JC, Wang L, Merlino G, Fausto N: Overexpression of transforming growth factor-alpha causes liver enlargement and increased hepatocyte proliferation in transgenic mice. Am J Pathol 1994; 145:398-408.

115 Yamada Y, Kirillova I, Peschon JJ, Fausto N: Initiation of liver growth by tumor necrosis factor: deficient liver regeneration in mice lacking type I tumor necrosis factor receptor. Proc Natl Acad Sci USA 1997;94:14411446.

-116 Rai RM, Lee FY, Rosen A, Yang SQ, Lin HZ, Koteish A, et al: Impaired liver regeneration in inducible nitric oxide synthase-deficient mice. Proc Natl Acad Sci USA 1998;95: 13829-13834.

117 Greenbaum LE, Li W, Cressman DE, Peng Y, Ciliberto G, Poli V, et al: CCAAT enhancer-binding protein beta is required for normal hepatocyte proliferation in mice after partial hepatectomy. J Clin Invest 1998; 102:996-1007.

118 Roselli HT, Su M, Washington K, Kerins DM, Vaughan DE, Russell WE: Liver regeneration is transiently impaired in urokinase-deficient mice. Am J Physiol 1998; 275:G1472-G1479.

119 Anderson SP, Yoon L, Richard EB, Dunn CS, Cattley RC, Corton JC: Delayed liver regeneration in peroxisome proliferator-activated receptor-alpha-null mice. Hepatology 2002;36:544-554.

120 Strey CW, Markiewski M, Mastellos D, Tudoran R, Spruce LA, Greenbaum LE, et al: The proinflammatory mediators C3a and $\mathrm{C} 5 \mathrm{a}$ are essential for liver regeneration. J Exp Med 2003;198:913-923.

-121 Leu JI, Crissey MA, Craig LE, Taub R: Impaired hepatocyte DNA synthetic response posthepatectomy in insulin-like growth factor binding protein 1-deficient mice with defects in C/EBP beta and mitogenactivated protein kinase/extracellular signal-regulated kinase regulation. Mol Cell Biol 2003;23:1251-1259.

122 Mohammed FF, Smookler DS, Taylor SE, Fingleton B, Kassiri Z, Sanchez OH, et al: Abnormal TNF activity in Timp3-/- mice leads to chronic hepatic inflammation and failure of liver regeneration. Nat Genet 2004;36:969-977.
123 Borowiak M, Garratt AN, Wustefeld T, Strehle M, Trautwein C, Birchmeier C: Met provides essential signals for liver regeneration. Proc Natl Acad Sci USA 2004;101: 10608-10613.

124 Oe S, Lemmer ER, Conner EA, Factor VM, Leveen $\mathrm{P}$, Larsson $\mathrm{J}$, et al: Intact signaling by transforming growth factor beta is not required for termination of liver regeneration in mice. Hepatology 2004;40:10981105.

125 Mitchell C, Nivison M, Jackson LF, Fox R, Lee DC, Campbell JS, et al: Heparin-binding epidermal growth factor-like growth factor links hepatocyte priming with cell cycle progression during liver regeneration. J Biol Chem 2005;280:2562-2568.

126 Oliver JR, Mara TW, Cherian MG: Impaired hepatic regeneration in metallothionein-I/II knockout mice after partial hepatectomy. Exp Biol Med (Maywood) 2005; 230:61-67.

127 Seki E, Tsutsui H, Iimuro Y, Naka T, Son G, Akira S, et al: Contribution of Toll-like receptor/myeloid differentiation factor 88 signaling to murine liver regeneration. Hepatology 2005;41:443-450.

128 Olle EW, Ren X, McClintock SD, Warner RL, Deogracias MP, Johnson KJ, et al: Matrix metalloproteinase- 9 is an important factor in hepatic regeneration after partial hepatectomy in mice. Hepatology 2006;44: 540-549.

129 Fernandez MA, Albor C, Ingelmo-Torres M, Nixon SJ, Ferguson C, Kurzchalia T, et al: Caveolin-1 is essential for liver regeneration. Science 2006;313:1628-1632.

130 Mayoral R, Fernandez-Martinez A, Roy R, Bosca L, Martin-Sanz P: Dispensability and dynamics of caveolin-1 during liver regeneration and in isolated hepatic cells. Hepatology 2007;46:813-822.

-131 Sigel B, Pechet G, Que MY, Macdonald RA: Tritiated thymidine autoradiography in the regenerating liver of the dog. J Surg Res 1965;5:72-78.

132 Sigel B, Baldia LB, Menduke H, Feigl P: Independence of hyperplastic and hypertrophic responses in liver regeneration. Surg Gynecol Obstet 1967;125:95-100.

133 Duguay LR, Orloff: Role of the pancreas in regulation of liver regeneration in dogs. Surg Forum 1977;28:387-390.

134 Gallot G, Gouet O, Bidallier M, Opolon CP, Huguet C: A simplified bloodless procedure for extensive hepatectomy. Eur Surg Res 1976;8:236-242.

135 Putnam CW, Porter KA, Starzl TE: Hepatic encephalopathy and light and electron micrographic changes of the baboon liver after portal division. Ann Surg 1976;184:155161.

$>136$ Camprodon R, Solsona J, Guerrero JA, Mendoza CG, Segura J, Fabregat JM: Intrahepatic vascular division in the pig. Arch Surg 1977;112:38-40. 
-137 Francavilla A, Porter KA, Benichou J, Jones AF, Starzl TE: Liver regeneration in dogs: morphologic and chemical changes. J Surg Res 1978 Nov;25:409-419.

138 Kahn D, Stadler J, Terblanche J, Van Hoorn-Hickman R: Thymidine kinase: an inexpensive index of liver regeneration in a large animal model. Gastroenterology 1980;79: 907-911.

- 139 Kahn D, van Hoorn-Hickamn R, Terblanche J: Liver blood flow after partial hepatectomy in the pig. J Surg Res 1984; 37:290-294.

$\checkmark 140$ Nordlinger B, Bouma ME, Wang SR, Ballet F, Verthier N, Huguet C, Infante R: Highyield preparation of porcine hepatocytes for long survival after transplantation in the spleen. Eur Surg Res 1985;17:377-382.

- 141 Francavilla A, Ove P, Polimeno L, Coetzee M, Makowka L, Rose J, Van Thiel DH, Starzl TE: Extraction and partial purification of a hepatic stimulatory substance in rats, mice and dogs. Cancer Research 1987;47: 5600-5605.

142 Kam I, Lynch S, Svanas G, Todo S, Polimeno L, Francavilla A, et al: Evidence that host size determines liver size: studies in dogs receiving orthotopic liver transplants. Hepatology 1987;7:362-366.

- 143 Kahn D, Hickman R, Terblanche J: A porcine model for the study of liver regeneration. J Invest Surg 1988;1:139-142.

144 Kahn D, Hickman R, Terblanche J, von Sommoggy S: Partial hepatectomy and liver regeneration in pigs - the response to different resection sizes. J Surg Res 1988; 45:176-180.

- 145 Kahn D, Hickman R, Terblanche J, Kirsch RE: Hepatic stimulator substance in extracts from regenerating porcine liver. Basic physiochemical properties. Eur Surg Res 1988;20:168-174.

- 146 Yanaga K, Kishikawa K, Suehiro T, Nishizaki T, Shimada M, Itasaka $H$, et al: Partial hepatic grafting: porcine study on critical volume reduction. Surgery 1995;118:486492.

-147 Chow PK, Jeyaraj P, Tan SY, Cheong SF, Soo KC: Serial ultrasound-guided percutaneous liver biopsy in a partial hepatectomy porcine model: a new technique in the study of liver regeneration. J Surg Res 1997;70:134-137.
148 Ogata A, Miyazaki M, Ohtawa S, Ohtsuka M, Nakjima N: Short-term effect of portal vein arterialization on hepatic protein synthesis and endotoxaemia after extended hepatectomy in dogs. J Gastroenterol Hepatol 1997; 12:633-638.

149 Sun L, Chow PK, Fook-Chong SM, Chew M, Aw SE, Soo KC: Liver regeneration after partial hepatectomy is non-uniform: flow cytometric bromodeoxyuridine incorporation and cell cycle studies in a porcine model. Res Exp Med (Berl) 1999;198:229-236.

150 Yabe S, Nishizawa H, Egawa H, Nakayama $\mathrm{H}$, Okamoto S, et al: Portal blood flow and liver regeneration in auxiliary partial orthotopic liver transplantation in a canine model. Eur Surg Res 1999;31:83-92.

151 Calise F, Di Floriro E, Mancini A, Mezza E Di Mino R, et al: Intrasplenic hepatocyte transplantation in the pig: new technical aspects. Transplant Proc 1997;29:19992001.

152 Lai OF, Chow PK, Tan S, Song IC, Soo, KC, et al: Changes in prostaglandin and nitric oxide levels in the hyperdynamic circulation following liver resection. J Gastroenterol Hepatol 2000;15:895-901.

153 Alvira LG, Herrera N, Salas C, Pereriar F, Herrera J, et al: Influence of cyclosporine on graft regeneration and function after liver transplantation: trial in pigs. Transplant Proc 2002;34:315-316.

154 Ishiguro S, Takada Y, Fukunaga K, Taniguchi H, Seino K, et al: Auxiliary partial orthotopic liver transplantation for fulminant hepatitis: regeneration of the diseased native liver in a pig model. Transplantation 2003;75:1901-1904.

155 Court FG, Wemyss-Holden SA, Morrison CP, Teague BD, Laws PE, Kew J, Dennison AR, Maddern GJ: Segmental nature of the porcine liver and its potential as a model for experimental partial hepatectomy. $\mathrm{Br} \mathrm{J}$ Surg 2003;90:440-444.
156 Mahlati G, Kahn D, Tyler M, Lotz Z, McLeod H, Hickman R: The regenerative response in intact young livers grafted into different sized recipient pigs. J Hepatol 1994;20:309-310.

157 Court FG, Laws PE, Morrison CP, Teague BD, Metcalfe MS, et al: Subtotal hepatectomy: a porcine model for the study of liver regeneration. J Surg Res 2004;116:181-186.

158 Ladurner R, Hochleitner B, Schneeberger S, Barnas U, Krismer A, et al: Extended liver resection and hepatic ischemia in pigs: a new, potentially reversible model to induce acute liver failure and study artificial liver support systems. Eur Surg Res 2005;37:365369.

159 Knubben K, Thiel C, Schenk M, Etspuler A, Schenk T, et al: A new surgical model for hepatectomy in pigs. Eur Surg Res 2008; 40:41-46.

160 Piecuch J, Orkisz W, Gabriel A, Sosada K, Zurawinski W, et al: Liver regeneration following portal blood arterialization and splenectomy in acute hepatic failure. Hepatogastroenterology 2007;54:1546-1550.

161 Pouyet M, Mechet I, Paquet C, Scoazec JY: Liver regeneration and hemodynamics in pigs with mesocaval shunt. J Surg Res 2007;138:128-134.

162 Wege H, Muller A, Muller L, Petri S, Petersen J, Hillert C: Regeneration in pig livers by compensatory hyperplasia induces high levels of telomerase activity. Comp Hepatol 2007;6:6.

163 Kano J, Ishiyama T, Lijima T, Morishita Y, Murata S, et al: Differentially expressed genes in a porcine adult hepatic stem-like cell line and their expression in developing and regenerating liver. Lab Invest 2008; 88:132-143.

164 Xia Q, Lu TF, Zhou ZH, Hu LX, Ying J, Ding DZ, et al: Extended hepatectomy with segments I and VII as resection remnant: a simple model for small-for-size injuries in pigs. Hepatobiliary Pancreat Dis Int 2008; 7:601-607.

165 Liska V, Treska V, Mirka H, Kobr J, Sykora $\mathrm{R}$, Skalicky T, et al: Interleukin-6 augments activation of liver regeneration in porcine model of partial portal vein ligation. Anticancer Res 2009;29:2371-2377. 